\title{
Statistical competence of principles of general secondary education institutions with basic natural or mathematical or humanitarian training
}

\section{Competencia estadística de los principios de las instituciones de educación secundaria general con formación básica natural, matemática o humanitaria}

\author{
Viktor Sychenko \\ Communal Institution of Higher Education «Dnipro Academy of Continuing Education» of \\ Dnipropetrovsk Regional Council, Dnipro, Ukraine. \\ ORCID: https://orcid.org/0000-0001-9655-2317 \\ Vadym Kirman \\ Communal Institution of Higher Education «Dnipro Academy of Continuing Education» of \\ Dnipropetrovsk Regional Council, Dnipro, Ukraine. \\ ORCID: https://orcid.org/0000-0002-8107-6618 \\ Tetiana Vilkhova \\ Communal Institution of Higher Education «Dnipro Academy of Continuing Education» of \\ Dnipropetrovsk Regional Council, Dnipro, Ukraine. \\ ORCID: https://orcid.org/0000-0003-3087-6532 \\ Vyacheslav Shynkarenko* \\ Communal Institution of Higher Education «Dnipro Academy of Continuing Education» of \\ Dnipropetrovsk Regional Council, Dnipro, Ukraine. \\ ORCID: https://orcid.org/0000-0003-0929-9160

\section{Tatyana Totochenko} \\ Communal Institution of Higher Education «Dnipro Academy of Continuing Education» of \\ Dnipropetrovsk Regional Council, Dnipro, Ukraine. \\ ORCID: https://orcid.org/0000-0003-2238-8635
}

Received 02-12-20 Revised 03-13-20 Accepted 07-13-20 On line 08-29-20

*Correspondence

Email: forte-pianoww@ukr.net
Cite as:

\footnotetext{
Sychenko, V., Kirman, V., Vilkhova, T., Shynkarenko, V., \& Totochenko, T. (2020). Statistical competence of principles of general secondary education institutions with basic natural or mathematical or humanitarian training. Propósitos y Representaciones, 8 (SPE2), e689. Doi: http://dx.doi.org/10.20511/pyr2020.v8nSPE2.689
} 


\section{Summary}

Statistical competence is defined as the leader's feature of character, which characterizes his willingness and ability to organize, to process and interpret information, needed to implement management processes. Statistical competence should be considered as a substructure of functional competence of the leader as it is shown in the article. The evaluation of indicators for the basic level of statistical competence for different categories of principles of educational institutions was carried out. It is shown that for managers with humanitarian and historical and science education the probability of distortion is not less than $20 \%$. In addition, the criterion of signs justifies the lack of effect of improving test results on the basics of mathematical and statistical literacy in the transition from a group of leaders with humanitarian, scientific and natural education. At the same time, the independence of the testing effectiveness on the basics of mathematical and statistical literacy of managers from teaching experience is shown. The obtained evaluation results and tested hypotheses indicate the need for the introduction of additional statistical education differentiated for groups of managers with mathematical education and natural sciences.

Keywords: Education; Educational Institution; Professional Competence; Principle of Educational Institution; Statistical Competence.

\section{Resumen}

La competencia estadística se define como la característica de carácter del líder, que caracteriza su disposición y capacidad para organizar, procesar e interpretar la información, necesaria para implementar procesos de gestión. La competencia estadística debe considerarse como una subestructura de la competencia funcional del líder, como se muestra en el artículo. Se realizó la evaluación de indicadores para el nivel básico de competencia estadística para diferentes categorías de principios de instituciones educativas. Se muestra que para los gerentes con educación humanitaria e histórica y científica, la probabilidad de distorsión no es inferior al $20 \%$. Además, el criterio de los signos justifica la falta de efecto de mejorar los resultados de las pruebas sobre los conceptos básicos de alfabetización matemática y estadística en la transición de un grupo de líderes con educación humanitaria, científica y natural. Al mismo tiempo, se muestra la independencia de la efectividad de las pruebas sobre los conceptos básicos de alfabetización matemática y estadística de los gerentes con respecto a la experiencia docente. Los resultados de evaluación obtenidos y las hipótesis probadas indican la necesidad de la introducción de educación estadística adicional diferenciada para grupos de gerentes con educación matemática y ciencias naturales.

Palabras clave: Educación; Institución educativa; Competencia profesional; Principio de Institución Educativa; Competencia estadística.

\section{Introduction}

Any management activity involves working with information, namely, data collecting, processing and interpreting, i.e. statistical analysis. Methodological and technical errors of statistical analysis can lead to contradictory or unfounded management decisions, distortion in the transfer of information to higher or one-tier chains of the hierarchical management system, distorted formation of public opinion. The role of the principle of a general secondary education institution in this process is very important, because the principle is responsible for the quality of information transmitted from the educational institution as information system to the environment and other systems, and the principle influences the organization of statistical activities (Bodnar, Mirkovich, Koval, 2019). Thus, statistical activity is natural for the work of the principle of general secondary education. So, it is very important to understand its content and be able to assess the readiness 
and ability of the principle to perform this activity. The latter depends on the training of the principle, his basic, usually pedagogical education.

In most cases, the principles of general secondary education institutions are former teachers with humanitarian and historical or natural and mathematical education, as well as teachers, who are "beginners" and psychologists. Special knowledge and skills of the educational manager under modern conditions teachers can receive at special courses or at training in Master Degree in "Educational management" specialization. At the same time, it becomes clear the possible relationship between the basic subject training of the teacher and his level of readiness to carry out statistical activities as a leader. In conclusion, we can say that the issue of theoretical and experimental analysis of the willingness of working principles of general secondary education institutions to carry out statistical activities is an urgent problem of practical importance. From the standpoint of modern methodology of education, this problem should be studied from the standpoint of a competency approach.

The selection of the necessary operational skills, epistemological institutions, their content analysis and measurement of appropriate levels should occur only in conjunction with analysis of the nature and content of current and future activities (Drobnic, 2019). In this case it is the principle of general secondary education institutions.

\section{Actual scientific researches and issues analysis}

The requirements to the professional activity of the principle of general secondary education institutions, formulated by Vilkhova, Moskalts, Rybkina (2019) and Sychenko (2019), Shynkarenko (2019), are obviously related to the requirements for the competencies of the principle. Relevant requirements formulated Davydova (2012), Pavlyutenko (2008), Shynkarenko (2020), Cebrian, Junyent, Mula (2020) are based on the definition of the competence of the principle of general secondary education.

Thus, Sorochan believes that "the professional competence of the principle of the SEI is the unity of psychological, theoretical and practical readiness for management in accordance with specific requirements and tasks" (Sorochan, 2005). Danylenko expresses a similar opinion, emphasizing that competence, as an integral leader's feature of character with an appropriate structure, should be aimed not only at carrying out the necessary activities, but also at finding the most effective solutions (Danylenko, 1998). Oleshko insists on the necessity to optimize management decisions in determining the competence of the principle of secondary education instituion, who also determines the components of the competence of the principle of secondary education instituion: management, pedagogical, communicative, diagnostic and research (Oleshko, 2008). Another component structuring is proposed by Martynenko (2012), Sychenko (2018), Koval, Polyezhayev, Bezkhlibna, (2018), Shynkarenko (2020). Strategic, social, functional, managerial and general professional competencies are namely distinguished (Bagmet, 2018; Bukanov et al., 2019).

It is obvious that the diagnostic and research components by Oleshko's classification (2008) and functional components by Martynenko's classification (2012) should contain a statistical subcomponent. Relevant issues of requirements, definitions and competence structures of the principle of educational institutions are covered in the following works by Bilyk (2019), Volotovskaya (2017), Pashko (2013), Sychenko (2018), Bitterova (2014), Shynkarenko (2018), 
Kvitka et al. (2019). At the same time, the issue of statistical activity of the principle of education and the separation of statistical competence as a component of the principle's competence in these works is not covered. We also do not know the works, where the level of awareness in the statistical analysis of the principle and the quality of management decisions are examined.

\section{Formulation of the goals of the article (task setting)}

The purpose of the article is to substantiate the existence and analysis of statistical competence as a subsystem of professional competence of the principle of secondary education institution. The objectives of the study are: to substantiate the necessaty to introduce the concept of "Statistical competence"; to find out its place in the system of professional competencies of the principle; to justify the structure and content of statistical competence; to develop approaches and basic tools for measuring the level of statistical competence of principles of secondary education institutions; to test the system of measuring the level of statistical competence of principles of secondary education institutions and to assess the state of readiness of working managers in order to perform basic tasks of statistical information processing.

\section{Scientific finding}

Theoretical developments offer different approaches to structuring the professional competence of the principle of an educational institution. It is necessary to take Martynenko's classification, as the basis (2012). It identifies strategic, social, functional, managerial and general professional competence. In its turn, functional competence is primarily connected with decision-making. However, any decision is based on the analysis of relevant information. This chain is fundamentally important for the formation of management decisions in the context of sustainable socio-economic development (Kostetska et al., 2020; Yankovyi et al., 2020). The task studying of the education leaders' competence is very important in the field of data analysis, which can be called as statistical competence.

The statistical competence of the principle characterizes his readiness and ability to organize collecting, processing and interpreting of information, which necessary for the implementation of management processes, i.e. to carry out statistical activities. Three components are closely related to each other, as well as to the methodological competence that defines the objectives of statistical research. The statistical activity of the principle may include the following elements: organization of information collecting, operational analysis of information, work with statistical experts. The sequence and activity of the principle's actions in carrying out his statistical activities is determined by the level of statistical competence of the principle. It is proposed to consider a two-dimensional model of statistical competence- (M: I). the first component reflects the mathematical and statistical component; the second one reflects operational and instrumental components, i.e. the ability to use digital technologies. The main priori assumption of our study is a high correlation of components $\mathrm{M}$ and I. It makes a possibility to perform level differentiation on only one scale, for example, $\mathrm{M}$, which leads instead of two-dimensional to one-dimensional scaling, in the first approximation. The choice of the first component $\mathrm{M}$ is due to the fact that this component is easier to measure, i.e. to build a test for understanding the basic mathematical facts. The formation of the content can be justified by the so-called competence-activity matrix (Table 1), which links the performance of certain professional activities in order to solve typical mathematical and statistical problems. The importance of the types of tasks in relation to the type of activity is assessed on a 4-point scale, namely: 0 is not important, 1 is rather not important than important, 2 is more important than not important, 3 is important. 
Table 1.

Competence and activity matrix of general secondary education institution principles

\begin{tabular}{|c|c|c|c|c|c|}
\hline Type of tasks $\backslash$ Activity & 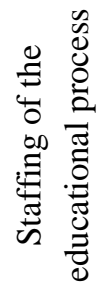 & 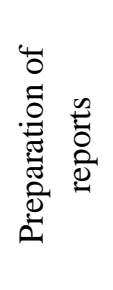 & 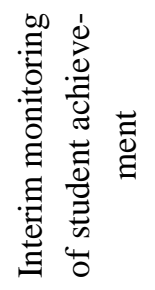 & 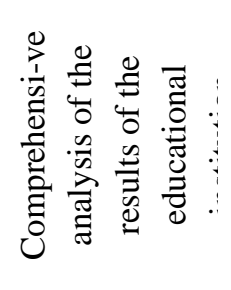 & 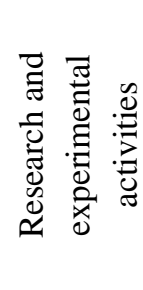 \\
\hline Operations with numbers & 2 & 3 & 3 & 3 & 3 \\
\hline Interest calculations & 3 & 3 & 3 & 3 & 3 \\
\hline $\begin{array}{l}\text { Analysis and construction of } \\
\text { graphs and charts }\end{array}$ & 3 & 3 & 3 & 3 & 3 \\
\hline $\begin{array}{l}\text { Work with samples, frequency } \\
\text { tables }\end{array}$ & 1 & 2 & 3 & 3 & 3 \\
\hline $\begin{array}{l}\text { Interpretation of measurement } \\
\text { scales }\end{array}$ & 0 & 1 & 3 & 3 & 3 \\
\hline $\begin{array}{l}\text { Selective calculations } \\
\text { characteristics and their } \\
\text { interpretation }\end{array}$ & 0 & 2 & 3 & 3 & 3 \\
\hline $\begin{array}{l}\text { Using basic } \\
\text { concepts of mathematical statistics }\end{array}$ & 0 & 1 & 2 & 2 & 3 \\
\hline $\begin{array}{l}\text { Self-solving } \\
\text { problems of classical mathematical } \\
\text { statistics }\end{array}$ & 0 & 0 & 1 & 1 & 3 \\
\hline $\begin{array}{l}\text { Nonparametric statistical methods } \\
\text { usage }\end{array}$ & 0 & 0 & 1 & 1 & 3 \\
\hline $\begin{array}{l}\text { Multidimensional statistical } \\
\text { analysis }\end{array}$ & 0 & 0 & 0 & 0 & 2 \\
\hline
\end{tabular}

Table 1 obviously defines the starting level of statistical competence required for the main activities of the manager. Then, it is necessary to describe the levels of statistical competence $M$ on the so-called recurrent principle. Each subsequent level will include the content of the previous plus "delta" (special content of the new level). That is, the following "formula" is valid:

$$
\mathrm{L}(i+1)=\mathrm{L}(i)+\mathrm{S}(i+1)
$$


Here $\mathrm{L}(i)$ is the content of the statistical competence of level $i, \mathrm{~S}(i)$ is the specific content of level $i$.

Analysis of possible statistical activities of the principle of an educational institution gives us the opportunity to identify 8 levels of his statistical competence: basic, primary, sufficient, secondary, high, basic professional, secondary professional and high professional. Thus, L(1) (basic level) includes the basics of mathematical literacy, i.e. the ability to operate with natural and integers, common and decimal fractions, basic problems on percentages, skills of analysis and construction of graphs and charts, finding measures of central trend in the simplest variants. Level L(2) is initial. A specific component for it S(2) includes: a) an idea of the measurement scales (nominal, binary, ordinal, relations, etc.); b) the ability of primary processing of statistical information together with the expert. Primary processing includes construction of a variation series, frequency tables, histograms, finding measures of the central tendency, namely: mean sample, mode, median, standard deviation, sample quantizes, etc. The specific component $\mathrm{S}(3)$ provides independent processing of primary statistical information is for level L(3) (sufficient). The specific component includes ideas about the classical concepts of mathematical statistics (confidence intervals, significance levels, correlation coefficients) and special characteristics, used in pedagogical measurements, for example, in psychometric characteristics of reports of the Ukrainian Center for Educational Quality Assessment or reports international monitoring programs are for the intermediate level L(4), the manager's ability to interpret documents, which provides relevant statistical characteristics. The specific component of high level $S(5)$ provides the ability to solve classical problems of mathematical statistics with the use of an expert. The basic professional level L(6) is used without the participation of an expert. Intermediate and advanced professional levels $\mathrm{L}(7)$ and $\mathrm{L}(8)$ include the ability to perform basic procedures of nonparametric and multidimensional statistical analysis, respectively.

This level classification is obviously quite approximate. Any statistical activity cannot be based only within mathematical operations, but it is closely related to the relevant subject area. The statistical analysis of the educational process is the most difficult one for the head of an educational institution. Lack of statistical literacy often leads to significant errors at different levels of the management hierarchy in the analysis of the effectiveness of learning processes. Here are some typical ones.

A. The arithmetic mean as the main indicator of success. In most cases, the arithmetic mean is incorrectly used in pedagogical measurements. This is primarily due to the fact that the results of educational achievements are given in ordinal rather than numerical scales, in which arithmetic operations are meaningless. In addition, for numerical data in psychological and pedagogical measurements, the so-called anomalous values are possible, which do not characterize the process as a whole; in such cases it is more correct to work with the median.

B. The neglecting of weight coefficients. A classical example of this great error: if you need to find the percentage of students of a given parallel, which showed a high level of academic achievement in the control section, some deputy principals simply find the arithmetic mean of percentages for classes of this parallel without taking into account the number of students in each class.

B. Integrated indicator of learning quality. It should be understood that according to the distribution of scores, no number (average, mode, median, quintile of given levels) can characterize the distribution as a whole, any characteristic describes it only partially. Thus, it is 
incorrect to assess the quality of education in this institution only by the percentage of students who scored more than 190 points in the external independent assessment.

D. Rating. This error is of the same nature as the previous one. Any rating is based on a certain algorithm, there can be many such algorithms, each of them cannot be preferred and they sometimes lead to conflicting data.

The list of such examples can be extended. At the same time, there are errors that are no longer related to the lack of basic statistical knowledge. These are errors of incorrect use of statistical methods. Most of all, this applies to the application of parametric methods of mathematical statistics where they do not work correctly. The most popular mistake is the incorrect use of Student's two-choice t-test. First of all, it can be used for small samples, when it is certain that it is a sample from the normal distribution. In most practical problems in pedagogical measurements it is impossible to check. You need to have a large sample and apply Pearson's criterion. Secondly, not less importantly, Student's t-test works, if the variances are equal. The corresponding hypothesis must be tested, for example, using the Snedekor-Fisher test.

In order to measure the level of statistical competence, we propose our own approach, which was proposed in (Kirman, 2017). First of all, it consists in the fact that it is necessary to abandon the single integrated indicator of the competence indicator. We consider the level indicator of statistical competence of the head for each of the entered levels. The level indicator is entered as follows: the population of typical tasks is considered for the corresponding level, which is divided into thematic clusters. Each cluster is associated with a specific type of task of the same level of complexity. A level indicator is defined as the probability of solving a randomly selected problem from a population of a given level. Obviously, then the value of the level indicator can be calculated by the formula of total probability:

$$
I=\sum_{k=1}^{m} \omega_{k} p\left(T_{k}\right)
$$

Where $I$ is the value of the level indicator, $p\left(T_{k}\right)$ is the probability of solving a type problem correctly $T_{k}$ from cluster numbered $k, \omega_{k}$ is probability (frequency) of using cluster tasks with a number $k$, where the condition of rationing is obviously fulfilled. The value $J=1-I$ can be interpreted as the probability of unintentional distortion of information due to insufficient statistical competence of the person.

The attempt was made in order to obtain an assessment of the level indicator for the first (basic) level of statistical competence for 125 principles of educational institutions, who took advanced training during 2018-2020. Due to the existing proportional system of specialist selections for advanced training courses according to the erode principle, this sample can be considered representative one. A mini-test on 10 questions was formed according to the content of the basic level. Thus, the following list of tasks was proposed: actions with integers and fractions, actions with decimal fractions, finding part of a number, finding the average weight percentage, qualitative analysis of the chart, quantitative analysis of the chart, comparative analysis of graphs and tables, finding measures of central trend (medians, fashion, arithmetic mean). Two important assumptions were made for further processing of the results. They are about the probability, which, for example, can be justified by the estimation Table 1, and the 
independence of the relevant issues. Then the score of the level indicator is the arithmetic mean of the points scored on a binary scale for each respondent.

Obviously, the proposed test concerned the simplest mathematical skills. So, all respondents were divided into three groups by subject-pedagogical education. Group A are specialists with historical and humanitarian education, Group B are specialists in natural sciences, Group $\mathrm{C}$ are specialists with mathematical and pedagogical education. Leaders, specialists in primary education, physical education and arts were joined to Group A. Information on the general characteristics of the level 1 (baseline) indicator scores for the three above-mentioned groups is given in Table 2, which also shows quite high values of unintentional distortion indices for groups A and В и $-22 \%$ and $27 \%$, respectively.

\section{Table 2.}

Characteristics of the central assessment tendency of the statistical competence indicator of the basic level for professional basic groups

\begin{tabular}{cccc}
\hline Feature \Group name & Group A & Group B & Group C \\
\hline Medium & 0.78 & 0.73 & 0.92 \\
\hline Median & 0.80 & 0.75 & 1 \\
\hline Modes & 0.80 & Bimodality: & 1 \\
& & $0.6 ; 0.9$ & \\
\hline
\end{tabular}

The distributions of the estimation of the indicator scores are shown in the diagrams (see Fig. 1-3). Visual analysis of the second diagram indicates the presence of a mixture of distributions, which are due to the fact that group B should be divided into two more homogeneous groups. A simple hypothesis here may be the selection of respondents with physical education, but, as a simple test in group B showed, the corresponding subgroup does not show better results. The division of group B should take place on another basis, which is unknown to the authors today.

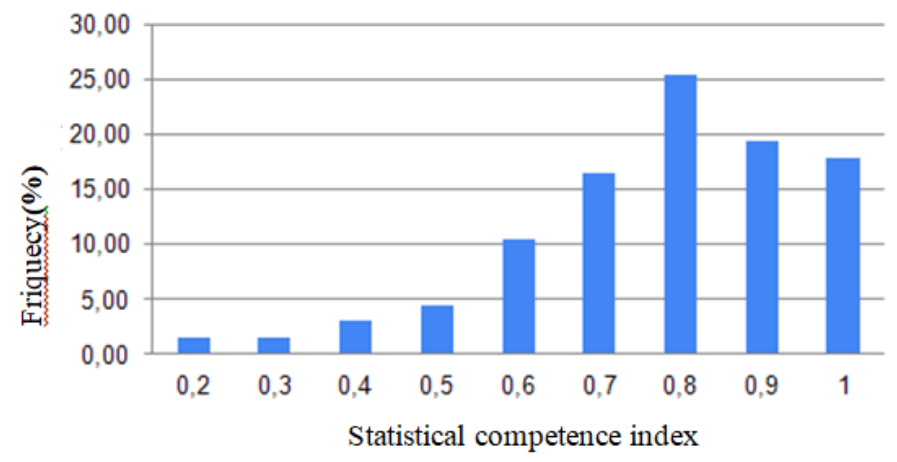

Figure 1. Diagram of estimation distribution of statistical competence index for group A 


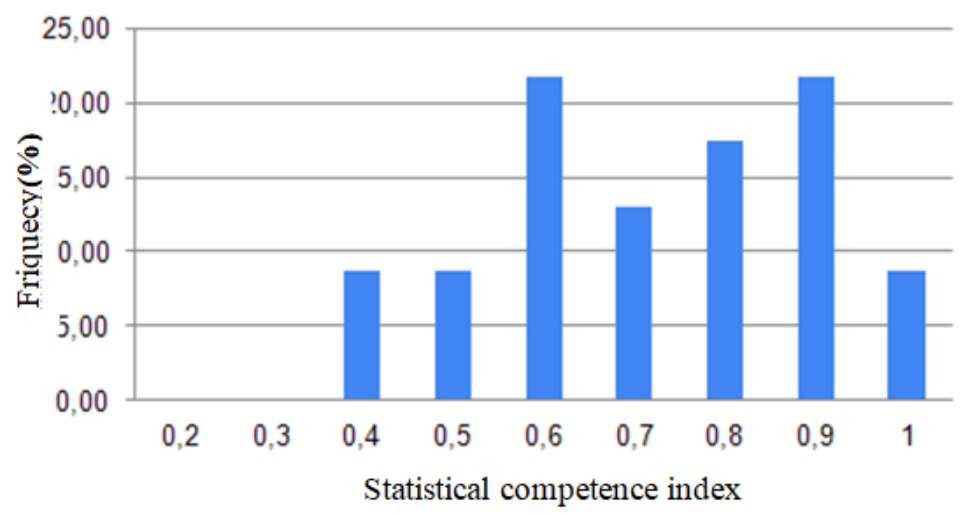

Figure 2. Diagram of estimation distribution of statistical competence index for group B

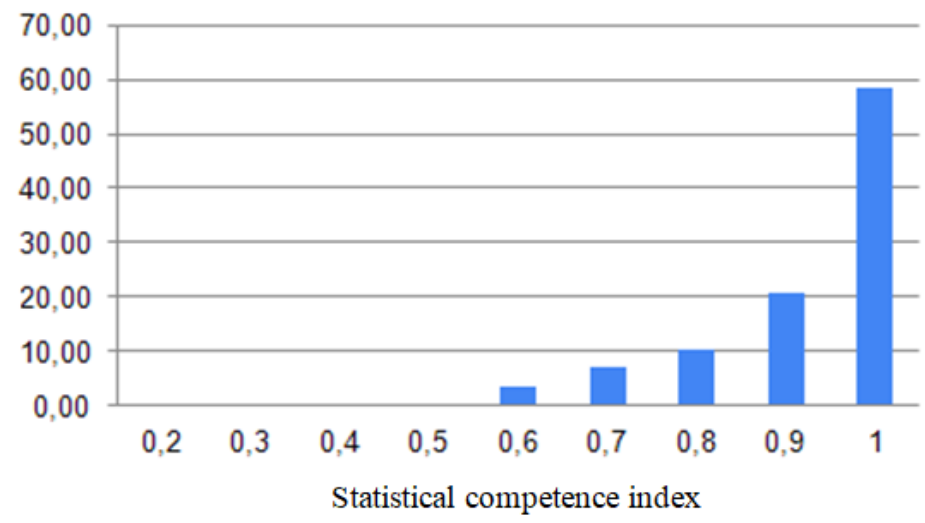

Figure 3. Diagram of estimation distribution of statistical competence index for group C

Analysis of Fig. 1-3 and Table 2 leads to the hypothesis of a positive dynamics of the competence index in the transition to the scheme B-C-A. Let's investigate this in more detail, using the criterion of signs (Turchyn, 2008).

We will use this interpretation. Let two groups of respondents (group 1 and group 2) be suggested tasks $1,2, \ldots, m$. Then we will consider the estimation $E_{1}^{1}, \ldots, E_{1}^{2}, \ldots, E_{m}^{2}$, which are the relative parts of the respondents in groups 1 and 2, who gave the correct answers to problems 1 , $2,3, \ldots, m$, respectively. This numbers will be considered as the values of some random variables. Consider the values $E_{i}=E_{i}^{2}-E_{i}^{1}$. We believe that $E_{i}$ can represented in the form $E_{i}=\theta+e_{i}$, where $e_{i}$, absolutely continuous random variables with symmetric relative as to zero distributions. Regarding the parameter $\theta$, we put forward the null hypothesis $H_{0}: \theta=0$ with the right-hand alternative $H_{1}: \theta>0$. Let $\mu$ be the number of positive estimation among $E_{i}$. According to the table of critical values of the criterion of signs (Turchyn, 2008).we set the right-hand critical value for the selected level of significance $\alpha-\mu_{\alpha ; m}$. If $\mu>\mu_{\alpha ; m}$, then the null hypothesis is rejected in favor of an alternative for this level of significance, which indicates the effect of "transition" 
from the first group to the second. If group B is considered the first one, and group A the second one, then the data on the complexity of the tasks for groups A and B (table 3) make it possible to calculate the statistics of the criterion $\mu=7$, at a significance level of 0.025 right critical value for 10 degrees of freedom is 8 (Turchyn, 2008), so the null hypothesis of the absence of a positive effect of group A in relation to group B is not rejected.

\section{Table 3.}

The complexity of the tasks of groups $A$ and $B$

\begin{tabular}{lcccccccccc}
\hline Task number & 1 & 2 & 3 & 4 & 5 & 6 & 7 & 8 & 9 & 10 \\
\hline $\begin{array}{l}\text { The share of respon-dents, who } \\
\text { coped in group A. }\end{array}$ & 0.45 & 0.76 & 0.92 & 0.77 & 0.94 & 0.79 & 0.91 & 0.59 & 0.79 & 0.85 \\
& & & & & & & & & & \\
\hline $\begin{array}{l}\text { The share of respon-dents, who } \\
\text { coped in group B. }\end{array}$ & 0.50 & 0.67 & 0.96 & 0.71 & 0.92 & 0.67 & 0.83 & 0.38 & 0.83 & 0.83 \\
& & & & & & & & & & \\
\hline $\begin{array}{l}\text { The difference in the shares of } \\
\text { respondents in groups A and B, who } \\
\text { coped }\end{array}$ & -0.05 & 0.09 & -0.03 & 0.06 & 0.02 & 0.12 & 0.08 & 0.22 & -0.1 & 0.02 \\
& & & & & & & & & & \\
\end{tabular}

Therefore, it can be argued that the performance of the test groups A and B do not differ significantly from each other. Therefore, we will combine them into one group D, which is compared with group B (table 4).

Table 4.

The difficulty of performing tasks in groups $\mathrm{C}$ and $\mathrm{D}$

\begin{tabular}{cccccccccccc}
\hline Task number & $\mathbf{1}$ & $\mathbf{2}$ & $\mathbf{3}$ & $\mathbf{4}$ & $\mathbf{5}$ & $\mathbf{6}$ & $\mathbf{7}$ & $\mathbf{8}$ & $\mathbf{9}$ & $\mathbf{1 0}$ \\
\hline $\begin{array}{c}\text { The share of respondents, } \\
\text { who coped in group C }\end{array}$ & 0.828 & 0.931 & 0.966 & 0.931 & 0.931 & 0.931 & 0.966 & 0.897 & 0.931 & 0.897 \\
\hline $\begin{array}{c}\text { The share of respondents, } \\
\text { who coped in group D }\end{array}$ & 0.467 & 0.733 & 0.933 & 0.756 & 0.933 & 0.756 & 0.889 & 0.533 & 0.800 & 0.844 \\
\hline $\begin{array}{c}\text { The difference in the shares of } \\
\text { respondents in groups C and } \\
\text { D, who coped }\end{array}$ & 0.361 & 0.198 & 0.032 & 0.175 & -0.002 & 0.175 & 0.077 & 0.363 & 0.131 & 0.052 \\
\end{tabular}

Group $\mathrm{C}$ is considered the second one, and group D the first one. The statistics of the sign criterion (C-D) is equal $\mu=9$. So, in this case the null hypothesis is rejected (the significance level was chosen 0.025$)$. So, we have the expected positive effect for group C. At the same time, comparative Table 1 and analysis of diagrams 1-3 indicates the same as in group C there are respondents, who assume simple mathematical errors, but the percentage of such respondents is very small.

Tables 3 and 4 allow us to identify the main "problem points" of basic mathematical and statistical training for managers. Groups A and B mainly concern actions with common and decimal fractions, work with percentage calculations, knowledge of simple characteristics of the central trend, such as the median. These problems can be easily solved by conducting one-day 
trainings on mathematical and statistical literacy. Note that when forming study groups for such trainings, it is possible to unite representatives, who have natural science and humanitarian education, but, preferably, not to be confused with leaders, who have mathematical education.

The dependence of the effectiveness of the basic statistical literacy test on pedagogical experience was also studied. Based on the conjugation table (table 5), we calculate Pearson's statistics for the criterion of independence.

Pearson's statistics are calculated according to the scheme:

$$
D=\sum_{i=1}^{s} \sum_{j=1}^{k} \frac{\left(h_{i, j}-t_{i} v_{j} / n\right)^{2}}{\left(t_{i} v_{j}\right) / n}
$$

In our case, $h_{i, j}$ the number of respondents, who scored points in between with pedagogical experience in between $j$. So, $t_{i}$ is total number of respondents, who received points in the interval $i, v_{j}$ is total number of respondents with pedagogical experience in the interval $j, s=3$ , $k=3$.

Table 5.

Table of conjugation for analysis of the dependence of experience and the test effectiveness on basic statistical literacy

\begin{tabular}{ccccc}
\hline Number of correct answers \Teaching experience & $\begin{array}{c}\text { Up to } \\
10 \\
\text { years }\end{array}$ & $\begin{array}{c}\text { From 11 } \\
\text { to 20 } \\
\text { years }\end{array}$ & $\begin{array}{c}\text { More } \\
\text { than 20 } \\
\text { years }\end{array}$ & Total \\
\hline Does not exceed 6 correct answers & 1 & 8 & 16 & 25 \\
\hline From 7 to 8 correct answers & 6 & 12 & 25 & 43 \\
\hline From 9 to 10 correct answers & 10 & 16 & 31 & 57 \\
\hline Total & 17 & 36 & 72 & 125 \\
\hline
\end{tabular}

Calculations give us value $D=2,74$. At the same time, the right-hand critical value of the $\chi^{2}$ distribution with 4 degrees of freedom at the significance level of 0.025 is 11.14 . So, because $D<\chi^{2}(0,25 ; 4)$ the null hypothesis of independence is not rejected. The practical application of the latter fact is the absence of the need for differentiation by teaching experience in the formation of groups for statistical training. At the same time, we have not been able to investigate the issue of dependence on seniority.

\section{Conclusions and directions for future research}

The necessity to separate statistical competence as a component of professional competence of the principle of an educational institution has been proved. It is approved that the content of statistical competence is determined by the leader's character. It has a hierarchical structure and 
it can be described in a recurrent way. It is desirable to have statistical competence at the second level, but the first basic one is required for the productive leader's management. The developed approach to measuring the levels of statistical competence allows us to estimate the index of unintentional distortion in information processing, as the probability of making an error in typical data processing problems. It is estimated that this index exceeds $20 \%$ for the simplest mathematical and statistical tasks for categories of managers, who do not have mathematical education. In order to reduce this index, it is desirable to conduct short-term mathematical and statistical training for managers.

Analysis of managers' test results showed the independence of the results from the teaching experience and the dependence only on the availability of mathematical education of the principle. It is important to pay attention to the applied aspect of the study. As it can be seen, there is a necessity to develop mathematical and statistical basic skills, especially for managers with nonmathematical general secondary education. The research allows you to properly differentiate students for such training. Relevant classes are also needed in education. This is possible through special trainings and thematic classes for managers to be held with those responsible for monitoring the quality of education. Strategically, it is necessary to realize that the level of statistical competence is influenced by significant training at the universities. Currently, more and more principles of educational institutions are majoring to apply for "Educational Management" at the Master degree. Specialists with humanitarian and science education, as a rule, have no idea about statistical methods at all, but teachers with mathematical education have only basic level. Therefore, the course of statistical methods, according to the authors, should become mandatory for graduate students studying educational management.

\section{Reference}

Bagmet, K. (2018). Regulation of Institutional Changes in the Social Sector of the National Economy: Conceptual Approach. Economics. Ecology. Socium, 2, 103-110.

Bilyk, N., Zolotukhina, S., \& Trubavina, I. (2019). Communicative competence as a professional quality of teacher for general secondary education. In Theory and practice of introduction of competence approach to higher education in Ukraine. Vienna: Premier Publishing.

Bitterova, M., Haskova, A., \& Pisonova, M. (2014). School Leader's Competencies in Management Area, Procedia Social and Behavioural Sciences, 49, 114-18.

Bodnar, S., Mirkovich, I., \& Koval, V. (2019). Human capital development in Ukrainian education system by means of language integrated teaching. Dilemas contemporaneoseducacion politica y valores, 7 (SI), 14.

Bukanov H., Kolesnyk A., Tashkinova O., Kotlubai V., \& Koval V. (2019). Social marketing in public administration of social service institutions. Revista Genero \& Direito, 8 (6), 457 468.

Cebrian, G., Junyent, M., \& Mula, I. (2020). Competencies in Education for Sustainable Development: Emerging Teaching and Research Developments, Sustainability, 12, 1-9.

Danylenko, L. (1998). Modernization of the content, forms and methods of management of the principal of the secondary school. K. : Lohos.

Davydova, N. (2012). Competence of the head of the educational institution, 50-54.

Drobnic, J. (2019). The Key Innovations in Career Guidance on Labour Market. Economics. Ecology. Socium, 3 (1), 12-22. https://doi.org/10.31520/2616-7107/2019.3.2-2

Kirman, V. (2017). Vector model of mathematical competence of a mathematics teacher and approaches to its identification. Topical issues of natural and mathematical education, 10, 57-69.

Kostetska, K., Khumarova, N., Umanska, Y., Shmygol, N., \& Koval, V. (2020). Institutional qualities of inclusive environmental management in sustainable economic development. Management Systems in Production Engineering, 28 (2), 15-22. 
Koval, V., Polyezhayev, Y., \& Bezkhlibna, A. (2018). Communicative competences in enhancing of regional competitiveness in the labour market. Baltic Journal of Economic Studies, 4(5), 105-113. doi:10.30525/2256-0742/2018-4-5-105-113

Kvitka, S., Starushenko, G., Koval, V., Deforzh, H., \& Prokopenko, O. (2019). Marketing of Ukrainian higher educational institutions representation based on modeling of Webometrics Ranking. Marketing and Management of Innovations, 3, 60-72. http://doi.org/10.21272/mmi.2019.3-05

Martynenko, S. (2012) Renewal of managerial functions of the head of a modern educational institution in the conditions of reforming the national education system. School management, 5, 8-9.

Oleshko, P. (2018). Formation of professional competence of the head of an educational institution in the conditions of innovative educational. Scientific journal NPU named after M.P. Drahomanova. Series 5. Pedagogical sciences: realities and prospects, 64, 156-162.

Pashko, L., Larina, N., \& Rudenko, O. (2013). Communicative competence of the leader. School management, 71-76.

Pavlyutenko E. (2008). Professional competence of the school principal. School management, 7, $2-4$.

Shynkarenko, V. (2018). Approaches and principles of patriotic education of senior pupils in the educational process of general education institutions. Scientific papers of Berdiansk State Pedagogical University. Series: Pedagogical sciences, 127-133. doi: 10.31494/24129208-2018-1-3-127-134.

Shynkarenko, V. (2019). Study of the status of patriotic education of senior administrators in general basic education staff. Scientific Issues of Vinnytsia State M. Kotsyubynskyi Pedagogical University. Section: Pedagogics and Psychology, 57, 56-60. doi: 10.31652/2415-7872-2019-57-56-60

Shynkarenko, V., Perederij, O., Bezena, I., Velykodna, Y., Miroshnychenko, A. (2020). Educational potential of and communication technologies in patriotic education of students. Revista Praxis Educacional, 16(37), 539-552. doi: 10.22481/praxisedu.v16i37.6404.

Sorochan, T. (2005). Preparation of school principals for managerial activity: theory and practice. Luhansk: Znannya.

Sychenko, V., Dreval, Yu., Sharovatova, O., Vilkhova, T. (2019). Methodological aspects of regulatory support of labor protection. Naukovyi Visnyk Natsionalnoho Hirnychoho Universytetu, 1, 104-109.

Sychenko, V., Marenichenko, V., Kozyryeva, O., Strapchuk, S. (2018). State regulation of formation small and medium businesses quality development based on grading. Financial and credit activities: problems of theory and practice, 1 (24), 205-212.

Sychenko, V., Pugach, A., Molodchenko, T., Tarasenko, T. (2018). Supervision and control of local self-government bodies in Ukraine: theoretical and legal approaches to clarification of concepts. Financial and credit activities: problems of theory and practice, 2 (25), 472479

Turchyn, V. ( 2008). Theory of Probability and Mathematical Statistics. Dnepropetrovsk: DNU.

Vilkhova, T., Moskalts, M., \& Rybkina, S. (2019). The main directions of public education management in terms of reform. Public administration and regional development, 4, 269290.

Volotovskaya, T. (2017). Theoretical aspects of managerial competence of heads of secondary schools. Bulletin of Chernihiv National Pedagogical University. Series: Pedagogical sciences, 142, 26-31.

Yankovyi O., Koval V., Trokhymets O., Karpenko M., \& Matskevich Y. (2020). Economic assessment of investment on the basis of production functions. Turismo: Estudos \&Práticas, 2. 